- allegedly stealing DNA constructs and cell lines from Okamoto's laboratory in the CCF's Lerner Research Institute.

This is thought to be the first time that molecular biologists have been charged under the 1996 Economic Espionage Act, which chiefly aims to deter theft of trade secrets in areas such as computing. It is also the first of about two dozen prosecutions under the act in which the theft is alleged to benefit a foreign government.

Okamoto, who researches Alzheimer's disease, is alleged to have taken reagents from the laboratory that he headed for two and a half years shortly before moving to RIKEN's Brain Science Institute. $\mathrm{He}$ is also accused of sabotaging reagents and laboratory notes. RIKEN is carrying out its own internal investigation, which Okamoto says will clear him of the charges.

Serizawa, now at the University of Kansas Medical Center, was arrested by the Federal Bureau of Investigation (FBI) on 9 May. He was charged with helping Okamoto take the samples to Japan and with giving false information to the FBI. Two other unnamed accomplices were not indicted.

The indictment charges that Okamoto and an unnamed co-conspirator entered Okamoto's lab on the evening of 8 July 1999, removed some DNA and cell lines and destroyed the rest. The next day, the missing reagents were noted and the police, and then the FBI, were informed.

"We thought that the police should be called in," says George Stark, director of the Lerner Institute. "There was no question about what to do." But some researchers expressed surprise at the FBI's involvement - especially given the frequency with which biologists take materials when they change jobs.

On 26 July, after the investigation into the case had started, Okamoto resigned his position at the CFF to start his new post at RIKEN on 3 August. According to the indictment, Okamoto had accepted the job at RIKEN in April 1999. The indictment also says that Okamoto had shipped the samples to Serizawa in Kansas City and then retrieved them during a short trip in mid-August.

Okamoto and Serizawa are alleged to have committed economic espionage by stealing "trade secrets" from the CCF, "specifically, 10 DNA and cell-line reagents", to benefit RIKEN.

The charge that the Japanese government benefited from an economic espionage crime is a politically sensitive one especially as the United States will need Japan's cooperation to extradite Okamoto.

Economic espionage charges carry a stiff penalty of up to 15 years in prison, $\$ 500,000$ in fines, or both. Okamoto and Serizawa are also charged with transport of stolen property across state lines and conspiracy.

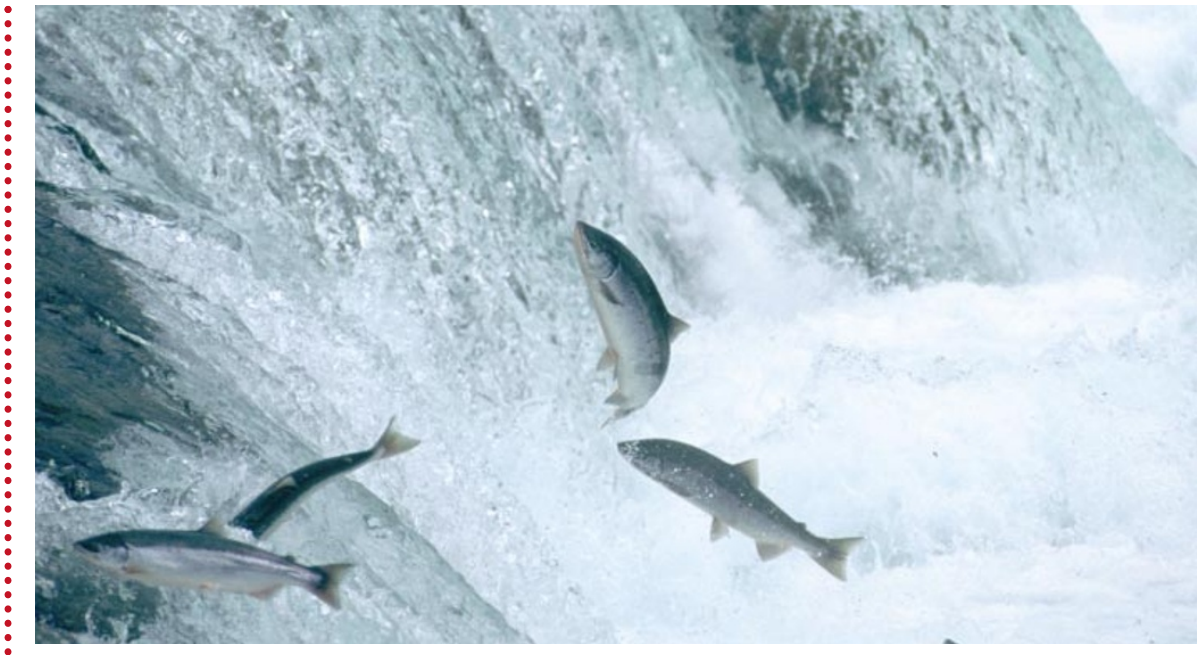

On the up: salmon populations have reached record levels in the rivers of the US Pacific northwest.

\title{
Record salmon populations disguise uncertain future
}

\section{Julie Wakefield, Washington}

Salmon are swimming up streams in the Pacific northwest from the ocean in record numbers this spring, raising questions about the measures needed to conserve them.

So far, more than 345,000 spring and summer chinook salmon (Oncorhynchus tshawytscha) have passed the lowermost Bonneville Dam on the Columbia River. And more than 115,000 of these have already hurled themselves past eight major dams and reached the Snake River to spawn in fresh waters - a 25 -fold increase on the average over the past 10 years.

Survival rates are also up. Scientists conservatively estimate that more than 21,000 wild chinook salmon, roughly $1.5 \%$ of recent years' smolt, will reach spawning grounds this season. This is more than double last year's figure of 8,900 and over 18 times the record low of 1,100 in 1995, according to fisheries biologist Charlie Petrovsky at the Idaho Department of Fish and Game.

Of the millions of smolt released from hatcheries in recent years to supplement the natural population, almost $1 \%$ survived the 1,000-kilometre journey. Survival rates in the past decade had been as low as $0.04 \%$.

This year's salmon run is the largest on the Columbia River Basin since records began in 1938, and the best for wild chinook since the late 1970s. It supports theories that ocean climate cycles are a key influence on salmon populations, researchers say.

"The increase in run size is due to increased survival in the ocean," says Ted Bjornn, a University of Idaho researcher who monitors runs.

Chinook are the most studied of the 26 salmon species listed under the US Endangered Species Act, and are considered a good barometer of salmon health in the Columbia River Basin, once the world's chinook capital.

But ecologists remain cautious. "These high returns should not cause us to assume the crisis is over and salmon are back," says Peter Kareiva, a conservation biologist at the National Marine Fisheries Service's Northwest Fisheries Science Center in Seattle. He says they reflect a period, beginning in 1999, of cooler waters, more food and fewer warmwater predators. Periods of warmer surface temperatures would, he says, put the pressure back on the salmon population.

Hydroelectric development, mining, overfishing, irrigation and urbanization have all been blamed for declining populations of wild salmon in the region. But with the population apparently surging - and electrical power growing short in the region (see opposite) — demands by environmentalists for dams on the Snake River to be demolished to conserve the salmon may lose momentum.

The new data are unlikely to quell controversy over management policies for the dams and rivers, however. In early May a coalition of environmental groups filed a suit against the National Marine Fisheries Service, alleging that its management plan for the salmon violates the Endangered Species Act. Environmentalists also claim that, under current policies, wild spring and summer chinook on the Snake River will be extinct by 2016 .

But Kareiva says the picture is far more complex than this. "Our analyses point to serious extinction risks, but also to considerable opportunities for recovery if improvements are made in several different risk factors - hatcheries, habitat, harvest and hydropower." Researchers estimate that full recovery of wild salmon will require a smolt survival rate of between 2 and $6 \%$. 